\title{
Photoprotective and Inhibitory Activity of Tyrosinase in Extract and Fractions of Terminalia catappa L.
}

\author{
Maulita Indrisari ${ }^{1,2 *}$, Sartini Sartini ${ }^{3}$, Upik A. Miskad ${ }^{4}$, Khairuddin Djawad $^{4}$, Karlina Amir Tahir ${ }^{1}$, Nurkhairi Nurkhairi ${ }^{2}$, Lukman Muslimin ${ }^{2}$ \\ ${ }^{1}$ Doctoral Program, Faculty of Medical, Hasanuddin University, Makassar, South Sulawesi, Indonesia; ${ }^{2}$ Sekolah Tinggi IImu \\ Farmasi Makassar, Makassar, South Sulawesi, Indonesia; ${ }^{3}$ Faculty of Pharmacy, Hasanuddin University, Makassar, South \\ Sulawesi, Indonesia; ${ }^{4}$ Faculty of Medicine, Hasanuddin University, Makassar, South Sulawesi, Indonesia
}

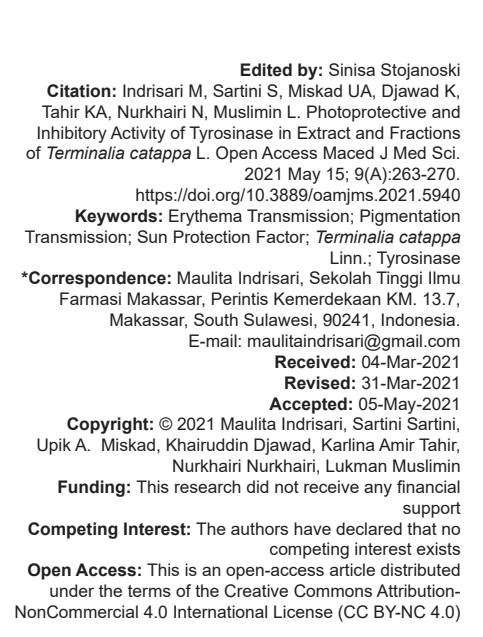

\begin{abstract}
BACKGROUND: Chronic exposure to ultraviolet (UV) radiation causes various skin damages. One of the most significant risks to skin occurrence is cancer and photoaging. Recent strategies for photoprotection have included incorporating natural sunscreens and antityrosinase.

AIM: This study aimed to determine the sun protection factor (SPF) and inhibitory activity of tyrosinase of the extract and fractions of leaves of Terminalia catappa Linn.

METHOD: The dried leaves were macerated with $96 \%$ ethanol and fractionated using n-hexane, ethyl acetate, and water. The extract and fractions were screened for their phytochemical profile, and tyrosinase inhibitory activity was evaluated and expressed as $\mathrm{IC}_{50}$. The photoprotective activity of extract and fractions were measured by a UV spectrophotometric.

RESULTS: Among the tested samples, the ethyl acetate fraction showed ultraprotection on erythema transmission rate (\%TE), sunblock on pigmentation transmission (\%TP), and minimum protection on SPF. Ethyl acetate fraction showed the highest activity to inhibit tyrosinase (IC50 was $50.54 \pm 2.37 \mu \mathrm{g} / \mathrm{mL}$ ). The phytochemical analysis of ethy acetate fraction revealed the presence of phenolic and flavonoid compounds.

CONCLUSION: This study's findings revealed a higher tyrosinase inhibitor and sun protection capacity of ethy
\end{abstract} acetate fraction of leaves of T. catappa and suitable to develop as a cosmetic agent.

\section{Introductions}

Becoming the largest organ of the human body, skin consists of $16 \%$ of body mass. Skin covers and protects everything inside the body. Normal human skin is organized into two primary layers, epidermis and dermis. The epidermis, of ectodermal origin, is the outer layer and direct contact with the environment. At the same time, the dermis is located inside and made up of epithelial, mesenchymal, glandular, and neurovascular components. Epidermis, with its physical characteristics, plays an important role in protecting the body from harmful chemicals such as infections, chemical agents, sharp objects, and ultraviolet (UV) radiation [1], [2], [3].

Prolonged exposure to UV radiation of human skin may cause several damages. These damages include skin cancer, sunburn, oxidative stress, and photoaging. The degree of damage depends on the amount and duration of exposure and the form and type of UV radiation [4]. Based on its wavelength, UV radiation is divided into three main segments which are UV C (100-290 nm), UV B (290-320 nm), and UV A $(320-400 \mathrm{~nm})$ [5].

The main important thing of UV radiation is leading to the formation of deoxyribonucleic acid (DNA) and changing between adjacent pyrimidine bases. Implication on unwanted protein production or broken cell or organ. These damaged DNA molecules can stimulate repair mechanisms known to cause inflammatory responses within the skin and increase the production of radicals. Free radical, singlet oxygen, and reactive oxygen species (ROS) can, in turn, cause other ROS, and in combination, attack cellular components such as cell membranes, cellular proteins, lipids, and nuclear and mitochondrial DNA. Many chromophores groups (chemicals capable of absorbing UV radiation and generating damaging ROS) exist within the skin by neutralizing the singlet racial oxygen [6].

Physiologically, antioxidant mechanism comes in the skin, including chemical and enzymatic 
antioxidants. Water-soluble antioxidants (Vitamin C, glutathione, lipoic acid, and uric acid) or lipid-soluble antioxidants (Vitamin E, ubiquinone, and carotenoids) are usually coming from diet and nutrition. Enzymatic antioxidants include superoxide dismutase (SOD), catalase, glutathione peroxidase, and glutathione transferase. Both chemical and enzymatic antioxidants protect the skin from damage by ROS and free radicals. However, with age and environmental stress, or chronic exposure can deplete the natural antioxidants, resulting in more vulnerable skin damage.[7], [8].

There has been an increasing interest in using antioxidants in sunscreens to provide supplemental photoprotective action activity. Antioxidants from natural sources may offer new possibilities for treating and preventing UV-mediated diseases. Therefore, natural products are essential sources for research in new active compounds to discover new biological mechanisms, obtain new active molecules, and study their structure-function relationships to develop more active drugs and avoid unwanted side effects [9], [10].

Wen et al., 2011, reported that water extract of Terminalia catappa protected skin from photodamage by inhibiting the mitogen-activated protein kinase (MAPK)/activator protein-1 (AP-1)/ matrix metalloproteinase (MMP) pathway [11]. The present study indicated that $T$. catappa exhibits potent free radical scavenging and antioxidant activity due to polyphenol and flavonoid content. The leaves extract of $T$. catappa protects the skin damage from radical $\mathrm{H}_{2} \mathrm{O}_{2}$ by inhibiting the protein expression of MMP, AP-1, MAPK, and cyclooxygenase-2 (COX-2) [12]. However, the activity and related mechanisms of $T$. catappa against UV oxidative stress-induced skin damaging are unclear. Therefore, this study investigated the effects of $T$. catappa ethanol extract and fractions to protect skin from UV radiation through the sun protection factor (SPF) value and their capability to inhibit tyrosinase.

\section{Materials and Methods}

\section{Materials}

Tyrosinase from the mushroom in lyophilized powder was obtained from Sigma Chemical Co. (St. Louis, USA). All chemicals and reagents used in the experiment were analytical grade and purchased from Sigma-Aldrich (St. Louis, USA).

\section{Sample collection and identification}

The leaves of T. catappa were collected from Makassar, South Sulawesi, Indonesia. The collected leaves were air-dried at $37^{\circ} \mathrm{C}$ for 3 hours and grounded into a powder. Identification and authentication of the plant were made by the Indonesia Institute of Science Research Center for Biology, Bogor, Indonesia.

\section{Extraction and fractionation}

The powdered form of air-dried leaves of T. catappa was subjected to macerate extraction using $96 \%$ ethanol. After complete extraction, the solvent was evaporated using a rotary evaporator (Büchi, German). Further, the ethanol extract $(3.0 \mathrm{~g})$ in water $(50 \mathrm{~mL})$ was extracted with two different solvents, which are hexane and ethyl acetate, using the liquid-liquid extraction (LLE) method, respectively. All the fractions were then dried in Freeze Dryer Lyophilizer (Büchi L200, German). The lyophilized powders were transferred into a vial and stored in a desiccator for subsequent analysis.

\section{Phytochemical screening}

\section{Flavonoids}

A total of $2.0 \mathrm{~g}$ of extract and fractions were dissolved in $2 \mathrm{~mL}$ of methanol, then $\mathrm{Mg}$ powdered, and five drops of $\mathrm{HCl}$ concentrated were added. The presence of flavonoids is indicated by the formation of red or orange colors [13].

\section{Phenolic}

The extract was added with $5 \% \mathrm{FeCl}_{3}$; a dark blue or black color is formed, which indicates a phenolic compound [14].

\section{Antityrosinase activity}

Antityrosinase activity was determined with the previous method describes by Wu et al., 2019 [15]. First, the extract and fractions were dissolved in dimethyl sulfoxide (DMSO) and diluted to seven different concentrations. The final concentration in water of the extract and fractions was $7.81 ; 15.63 ; 31.25 ; 62.50 ; 125.00 ; 250.00$; and $500.00 \mu \mathrm{g} / \mathrm{mL}$. Subsequently, $30 \mu \mathrm{L}$ of the extract and fractions was mixed with $100 \mu \mathrm{L}$ sodium phosphate buffer (0.05 mM), and $100 \mu \mathrm{L}$ of $100 \mathrm{mg} / \mathrm{L} \mathrm{L}$-tyrosine and $20 \mu \mathrm{L}$ of tyrosinase solution (350 units $/ \mathrm{mL}$ ) were next added. This reaction solution was homogeneously mixed and incubated at room temperature. The final absorbance was recorded at $490 \mathrm{~nm}$ using a microplate reader after $20 \mathrm{~min}$ of incubation. The concentration of extract and fractions at which $50 \%$ of the original tyrosinase activity is inhibited $\left(\mathrm{IC}_{50}\right)$ was determined for extract and fractions. The antityrosinase activity of the extract and fractions leaves of $T$. catappa is expressed as a percentage of tyrosinase inhibition as follows:

Tyrosinase inhibition $(\%)=\frac{A_{\text {control }}-A_{\text {sample }}}{A_{\text {control }}} \times 100$ 


\section{In vitro sunscreen activity}

\section{Preparation of solution}

The ethanol extract was dissolved in ethanol to a final concentration of $50.0 ; 75.0 ; 100.0 ; 125.0$; and $150.0 \mu \mathrm{g} / \mathrm{mL}$. Hexane fraction was dissolved in ethanol to a final concentration of $60.0 ; 120.0 ; 180.0 ; 240.0$; and $300.0 \mu \mathrm{g} / \mathrm{mL}$; ethyl acetate fraction was dissolved in ethanol to a final concentration 32.0; 48.0; 64.0; 80.0; and $96.0 \mu \mathrm{g} / \mathrm{mL}$; while water fraction was dissolved in ethanol to a final concentration of $50.0 ; 75.0 ; 100.0$; 125.0; and $150.0 \mu \mathrm{g} / \mathrm{mL}$.

\section{erythema (TE)}

\section{Determination of percent transmission of}

The TE value was determined using a UV spectrophotometer (Shimadzu UV-1800) by measuring the transmittance of several concentrations of the sample solution at the wavelength causing erythema of 292.5-372.5 nm at $5 \mathrm{~nm}$ intervals with ethanol as the blank. The TE value was calculated by:

$$
T E=\frac{\text { serythematransmission }(T x F e)}{\Sigma \text { flux erythema }(F e)} \times 100
$$

\section{Determination of percent transmission of pigmentation (TP)}

The TP value was determined using a UV spectrophotometer (Shimadzu UV-1800) by measuring the transmittance of several concentrations of the sample solution at the wavelength causing erythema of $292.5-372.5 \mathrm{~nm}$ at $5 \mathrm{~nm}$ intervals with ethanol as the blank. The TP value was calculated by:

$$
T P=\frac{\Sigma \text { pigmentation transmission }(T x F p)}{\Sigma \text { flux pigmentation }(F p)} \times 100
$$

\section{Determination of SPF}

The SPF model used in this study was according to the methodology described by Costa et al. (2015). The sample absorbances were measured in wavelength range $292.5-372.5 \mathrm{~nm}$, with $5 \mathrm{~nm}$ increments, and three determinations were made at each point [16]. The SPF value is calculated using the formula:

Area Under Curve $(\mathrm{AUC})=\frac{A a+A b}{2} \times\left(\mathrm{dP}_{\mathrm{a}-\mathrm{b}}\right)$

$\log \mathrm{SPF}=\frac{A U C}{\lambda n-\lambda 1} \times \mathrm{DF}$

Where:

$A_{a}=$ Absorbance in wavelength a $\mathrm{nm}$
$A_{b}=$ Absorbance in wavelength $b \mathrm{~nm}$

$\mathrm{dP}_{\mathrm{a}-\mathrm{b}}=$ Difference in wavelengths $\mathrm{a}$ and $\mathrm{b}$

$\lambda n=$ The largest wavelength (with $A \geq 0.05$ )

$\lambda_{1}=$ Smallest wavelength $(290 \mathrm{~nm})$

$\mathrm{DF}=$ Dilution factor.

\section{Data analysis}

The analyses were performed in triplicate, and the results expressed as mean \pm standard deviation (SD).

\section{Results}

The yields for the dried extract and fractions in each solvent are presented in Table 1. The results showed that the percentage of ethanol extract yield was $28.08 \%$. After fractionation, the fraction showed a pattern for percent yield, as follows: Water $>h$-hexane >ethyl acetate. These results indicated that the leaves of $T$. catappa primarily contain polar compounds.

Table 1: The yields of leaves of $T$. catappa extracts and fractions prepared using different extraction solvents

\begin{tabular}{ll}
\hline Sample & Yield (\%) \\
\hline Ethanol extract & 28.08 \\
Hexane fraction & 11.30 \\
Ethyl acetate fraction & 4.66 \\
Water fraction & 15.97 \\
\hline
\end{tabular}

Phytochemical screening was carried out on extract and fractions of leaves of $T$. catappa using a color reaction or precipitation. From the results of the tests conducted, it was stated that the extract and all fractions contained flavonoid and phenolic compounds, except hexane only phenolic (Table 2 ).

Table 2: Phytochemical screening of extract and fractions of leaves of T. catappa

\begin{tabular}{lll}
\hline Sample & Parameters & \\
\cline { 2 - 3 } & Flavonoid & Phenolic \\
\hline Ethanol extract & + & + \\
Hexane fraction & - & + \\
Ethyl acetate fraction & + & + \\
Water fraction & + & + \\
\hline
\end{tabular}

The effectiveness of the leaves of T. catappa as sunscreen is based on the percentage of TE and TP, and also SPF value. The concentrations of extract and fractions were used in this study, which were 32.0 till $300 \mu \mathrm{g} / \mathrm{mL}$. The selection of concentrations is based on optimization results as well to see the effect of increased fraction concentration on sunscreen activity. The present value of \%TE, as well as the \%TP, shows that both extract and fractions an increase in concentration indicates a decrease in value of leaves of T. catappa (Figures 1 and 2). This illustrates that all samples can absorb UV light and reduce the side effect of exposure received by the skin, but ethyl acetate fraction is more active than others.

Table 3 shows the protection categories of extract and fractions of leaves of T. catappa. Ethanol 


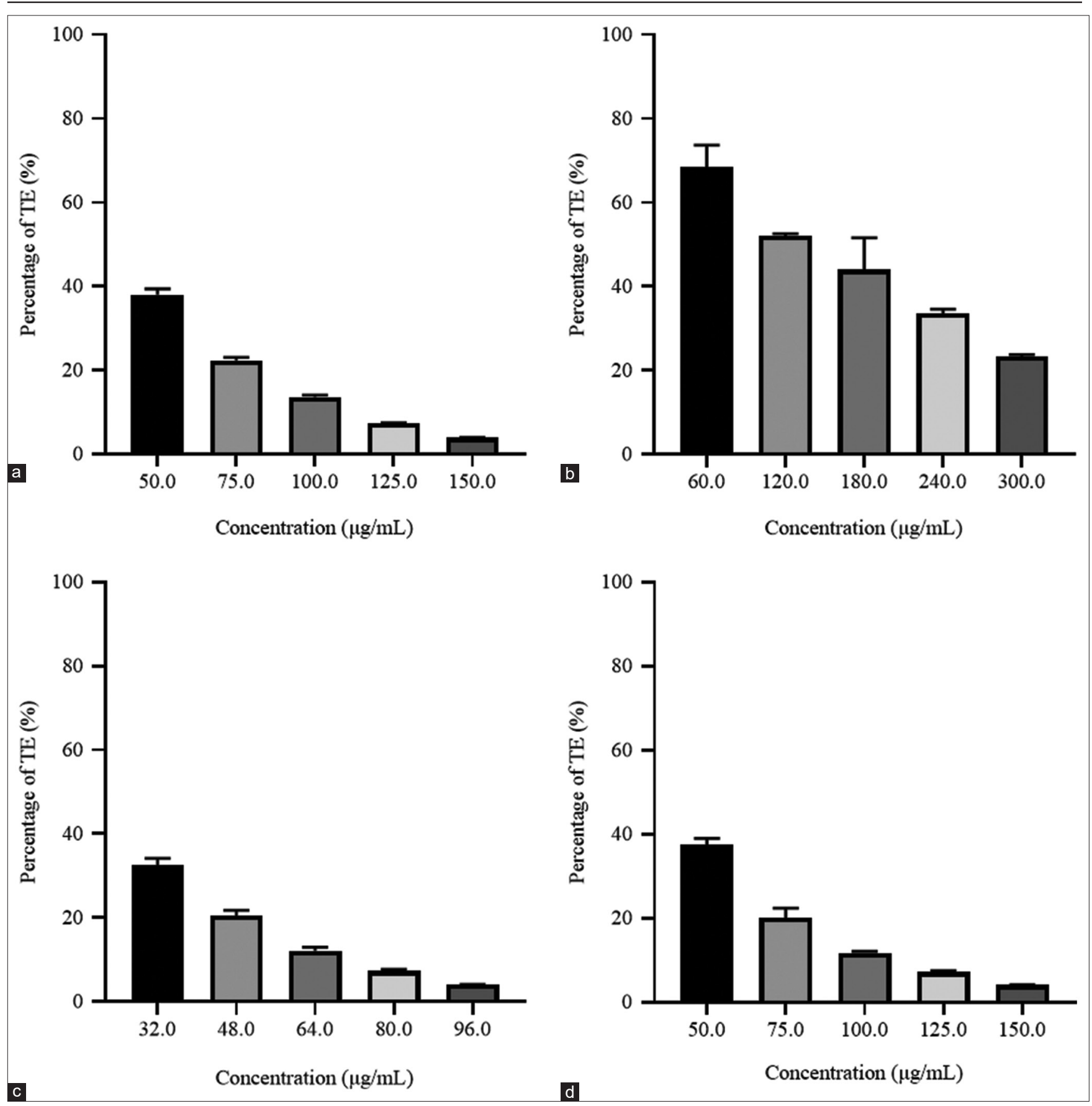

Figure 1: Percentage transmission of erythema of leaves of T. catappa: Ethanol extract (a); hexane fraction (b); ethyl acetate fraction (c); water fraction (d). Data are expressed as the means $\pm S D$ of three independent experiments

extract at the concentration 100.0 till $150.00 \mu \mathrm{g} / \mathrm{mL}$ has minimum category; hexane fraction at the concentration 60.0 till $300 \mu \mathrm{g} / \mathrm{mL}$ no showing activity; ethyl acetate fraction at the concentration 64.9 till $96.0 \mu \mathrm{g} / \mathrm{mL}$ has minimum category; while water fraction at the concentration 100.0-150.0 $\mu \mathrm{g} / \mathrm{mL}$ has a minimum category. From this result, extract and fractions have a minimum category at a specific concentration, except hexane fraction.

Inhibition on tyrosinase was evaluated to measure the ability of extract and fractions to interrupt this enzyme. The result showed that both extract and fractions could inhibit tyrosinase activity in a dose-dependent manner at a concentration of 7.81-500.00 $\mu \mathrm{g} / \mathrm{mL}$ (Figure 3). The most pronounced inhibition was observed in the ethyl acetate fraction. This can be seen from the lowest IC ${ }_{50}$ value compared to the others (Table 4).

\section{Discussion}

The aim of SPF measurement is quantitative of the effectiveness of a sunscreen. To effectively prevent 

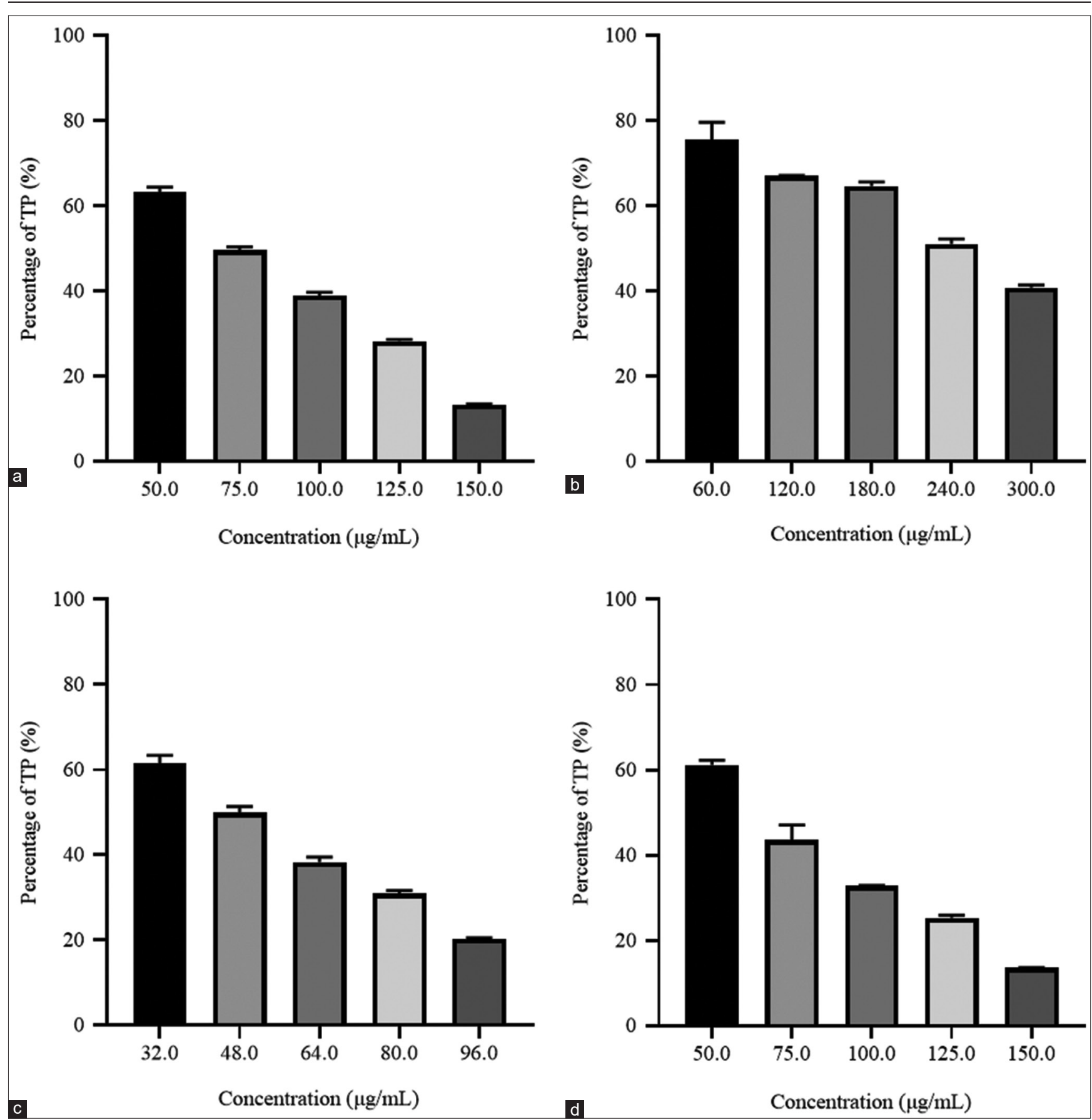

Figure 2: Percentage transmission of pigmentation of leaves of Terminalia catappa: Ethanol extract (a); hexane fraction (b); ethyl acetate fraction (c); water fraction (d). Data are expressed as the means $\pm S D$ of three independent experiments

sunburn and other skin damage, a sunscreen product should have a wide range of absorbance between 290 and $400 \mathrm{~nm}$ [17]. In this research, the ethanol extract and its fractions of leaves of $T$. catappa were evaluated by UV spectrophotometry applying a mathematical equation.

The leaves of $T$. catappa were extracted with $96 \%$ ethanol using the maceration method. The extraction process steps are size reduction, extraction, filtration, concentration, and drying [18]. The solvent depends on the type of bioactive compounds that will be extracted. In general, polar solvents such as water are used to extract polar compounds, non-polar solvents such as hexane are used to extract nonpolar compounds. In contrast, semi-polar like ethanol can extract both polar and non-polar compounds. LLE method was used to divide the active compounds based on their polarity. Non-polar compounds will accumulate in hexane fraction, slightly polar compounds will accumulate in ethyl acetate fraction, while polar compounds will accumulate in water fraction (residue).

Phytochemical screening was carried out on extract and fractions of leaves of T. catappa using a color reaction or precipitation. It was stated that the extract and all fractions contained flavonoid and phenolic compounds, except hexane only phenolic. The 
Table 3: Protection categories based on SPF values of extract and fractions of leaves of $T$. catappa

\begin{tabular}{llll}
\hline Sample & $\begin{array}{l}\text { Concentration } \\
(\mu \mathrm{g} / \mathrm{mL})\end{array}$ & SPF value & Protection category \\
\hline Ethanol extract & 50.0 & 1.44 & - \\
& 75.0 & 1.76 & - \\
& 100.0 & 2.09 & Minimal protection \\
& 125.0 & 2.74 & Minimal protection \\
Hexane fraction & 150.0 & 3.68 & Minimal protection \\
& 60.0 & 1.16 & - \\
& 120.0 & 1.32 & - \\
Ethyl acetate fraction & 180.0 & 1.37 & - \\
& 240.0 & 1.54 & - \\
& 300.0 & 1.77 & - \\
& 32.0 & 1.51 & - \\
Water extract & 48.0 & 1.80 & - \\
& 64.0 & 2.23 & Minimal protection \\
& 80.0 & 2.71 & Minimal protection \\
& 96.0 & 3.51 & - \\
& 50.0 & 1.44 & - \\
& 75.0 & 1.84 & Minimal protection \\
& 100.0 & 2.27 & Minimal protection \\
& 125.0 & 2.76 & Minimal protection \\
\hline
\end{tabular}

high amounts of phenolic influence sunscreen activity. The phenolic compound in the extract has conjugated bonds in the benzene core. When exposed to UV light, resonance occurs through electronic transfer. The standard conjugation system for phenolic compounds and chemicals usually contained in sunscreens gives these compounds the potential to be photoprotective. Flavonoid is the largest group of phenolic compounds. Flavonoid also has potential as sunscreens because of chromophore groups' presence, which generally gives plants a yellow color. The conjugated aromatic system becomes the identity of flavonoid, which provides a powerful ability to absorb light of UV A and UV B [19].

Table 4: The $\mathrm{IC}_{50}$ values of the extract and fractions of leaves of $T$. catappa on the tyrosinase activity

\begin{tabular}{ll}
\hline Sample & $\mathrm{IC}_{50}(\mu \mathrm{g} / \mathrm{mL})$ \\
\hline Ethanol extract & $93.01 \pm 2.28$ \\
n-hexane fraction & $275.93 \pm 67.74$ \\
Ethyl acetate fraction & $50.54 \pm 2.37$ \\
Water fraction & $123.12 \pm 2.01$ \\
\hline
\end{tabular}

The percentage of erythema transmission describes the amount of sunlight transmitted after being exposed to sunlight, causing skin pigmentation. Based on this, the lower the percentage value of erythema and pigmentation transmission means that the sunscreen's potential to protect the skin is better than a bigger concentration. However, SPF is a universal indicator that explains the effectiveness of a product or substance that is a UV protector. The higher the SPF value of a product or active sunscreen, the more effective it is to protect the skin from the destructive effects [20], [21]. UV B light induces sunburn (burning skin), at high and long exposure induces skin cancer formation. Even though UV A amount reaches to earth is $10 \%$ more than UV B, more erythema production is caused by UV B [22]. Substances can provide a protective effect as a sunscreen if its SPF value is $>2$ [23]. On 2009, European Commission (EC) classified SPF value as the following: Low protection (SPF 6-10), protection (SPF 15-25), high protection (SPF 30-50), and extremely high protection (SPF >50) [24]. In fact, the higher the SPF value desired, the higher the amount of active substance is

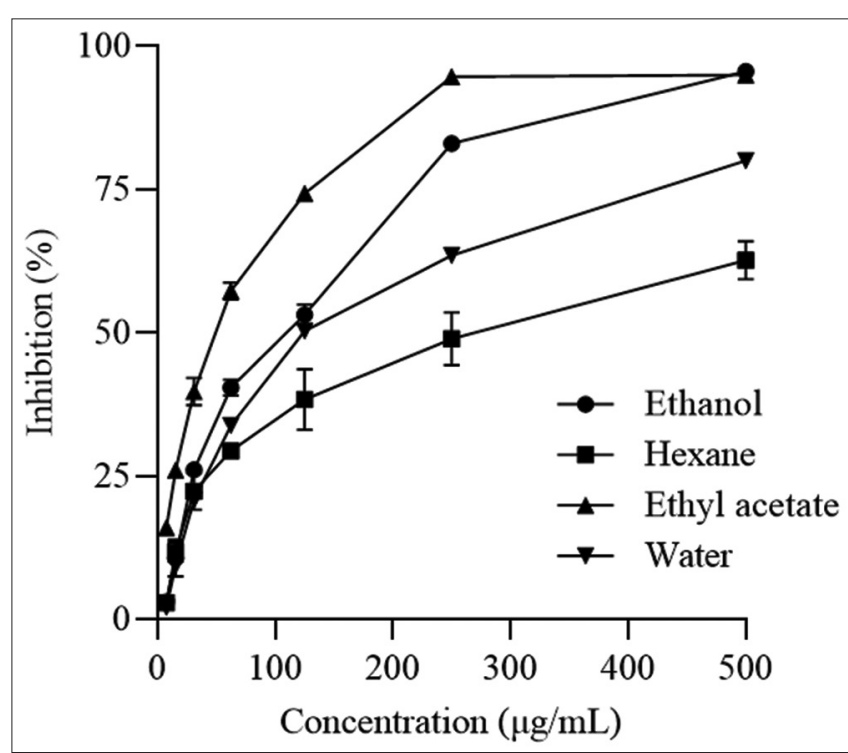

Figure 3: The inhibition effects Terminalia catappa extract and fractions on tyrosinase activity. Data are expressed as the means \pm $S D$ of three independent experiments

needed to be added. A substance can provide a protective effect as a sunscreen if its SPF value is $>2$ [23].

The actual skin color is affected by many substances, but the mostimportant substance is melanin. Melanin causes the skin color of darker human skin and produces within the melanocytes cell. Melanin synthesis was catalytic by the enzyme tyrosinase. Tyrosinase catalyzes L-tyrosine to L-3.4-dihydroxyphenylalanine (DOPA) and subsequently oxidized become dopachrome. [25]. Therefore, tyrosinase inhibitors can be used to avoid skin pigmentation both in medicine and in cosmetics. The most pronounced inhibition was observed in the ethyl acetate fraction. The highest activity can be inferred from the presence of phenolic and flavonoid compounds. Much literature describes that these compounds are responsible mainly for the inhibition of tyrosinase activity [26], [27].

T. catappa and its constituents have shown many beneficial pharmacological potentials. Free radical, 1,1-diphenyl-2-picrylhydrazyl, can be scavenged by methanol extract of $T$. catappa able to scavenge [28]. The free radicals are the main risk of skin damage. Presenting antioxidants can stimulate the skin to repair and build itself naturally. Strong antioxidants protect humans from free radicals or oxidative stress. Several studies have indicated that strong antioxidants from natural ingredients are able to resist oxidative damage to the skin because of free radicals [29], [30].

\section{Conclusion}

This study showed that the ethyl acetate of leaves of T. catappa exhibited higher SPF activities 
compared to the ethanol, hexane, and water fraction. The SPF activity of ethyl acetate fraction could be attributed to their relatively content phenolic and flavonoid. These fractions can, therefore, be proposed as new potential sources of natural additives for cosmetics.

\section{References}

1. Lowe NJ. An overview of ultraviolet radiation, sunscreens, and photo-induced dermatoses. Dermatol Clin. 2006;24(1):9-17. https://doi.org/10.1016/j.det.2005.08.001

PMid:16311163

2. Young $A R$, Claveau J, Rossi AB. Ultraviolet radiation and the skin: Photobiology and sunscreen photoprotection. J Am Acad Dermatol. 2017;76(3):S100-9. https://doi.org/10.1016/j. jaad.2016.09.038 PMid:28038885

3. Bissonnette R, Claveau J, Gupta AK. Ultraviolet a radiation and the need for protection. J Cutan Med Surg. 2006;10(Suppl 3):S1-7. https://doi.org/10.2310/7750.2006.00025

4. Matsumura $\mathrm{Y}$, Ananthaswamy $\mathrm{H}$. Toxic effects of ultraviolet radiation on the skin. Toxicol Appl Pharmacol. 2004;195(3):298308. https://doi.org/10.1016/j.taap.2003.08.019 PMid:15020192

5. Norval M, Lucas RM, Cullen AP, de Gruijl FR, Longstreth J, Takizawa Y, et al. The human health effects of ozone depletion and interactions with climate change. Photochem Photobiol Sci. 2011;10(2):199-225. https://doi.org/10.1039/c0pp90044c PMid:21253670

6. Bickers DR, Athar M. Oxidative stress in the pathogenesis of skin disease. J Invest Dermatol. 2006;126(12):2565-75. https:// doi.org/10.1038/sj.jid.5700340

PMid:17108903

7. Kurutas EB. The importance of antioxidants which play the role in cellular response against oxidative/nitrosative stress: Current state. Nutr J. 2016;15:e71. https://doi.org/10.1186/ s12937-016-0186-5

PMid:27456681

8. Tan BL, Norhaizan ME, Liew WPP, Rahman HS. Antioxidant and oxidative stress: A mutual interplay in age-related diseases. Front Pharmacol. 2018;9:e1162. https://doi.org/10.3389/ fphar.2018.01162

PMid:30405405

9. Ebrahimzadeh MA, Enayatifard R, Khalili M, Ghaffarloo M, Saeedi M, Yazdani Charati J. Correlation between sun protection factor and antioxidant activity, phenol and flavonoid contents of some medicinal plants. Iran J Pharm Res. 2014;13(3):1041-7. PMid:25276206

10. Lorigo M, Cairrao E. Antioxidants as stabilizers of UV filters: An example for the UV-B filter octylmethoxycinnamate. Biomed Dermatol. 2019;3:e11. https://doi.org/10.1186/ s41702-019-0048-9

11. Wen KC, Shih IC, Hu JC, Liao ST, Su TW, Chiang HM. Inhibitory effects of Terminalia catappa on UVB-induced photodamage in fibroblast cell line. Evid Based Complement Alternat Med. 2011;2011:e904532. https://doi.org/10.1155/2011/904532 PMid:20981325

12. Huang YH, Wu PY, Wen KC, Lin CY, Chiang HM. Protective effects and mechanisms of Terminalia catappa L. methanolic extract on hydrogen-peroxide-induced oxidative stress in human skin fibroblasts. BMC Complement Altern Med. 2018;18:e266. https://doi.org/10.1186/s12906-018-2308-4

PMid:30285714

13. Pertiwi DI, Naufalin R, Arsil P, Erminawati, Wicaksono $R$, Auliya T. Quality of simplician bioactive components and liquid extract of kecombrang flower powder from temperature and time optimization results. IOP Conf Ser Earth Environ Sci. 2019;406:e012008. https://doi. org/10.1088/1755-1315/406/1/012008

14. Putra IB, Jusuf NK, Sumantri IB. The potency of Hibiscus rosa-sinensis Linn. Leaves ethanol extract as hair growth. Open Access Maced J Med Sci. 2020;8(A):89-92. https://doi. org/10.3889/oamjms.2020.4211

15. Wu L, Chen C, Cheng C, Dai H, Ai Y, Lin C, et al. Evaluation of tyrosinase inhibitory, antioxidant, antimicrobial, and antiaging activities of Magnolia officinalis extracts after Aspergillus niger fermentation. Biomed Res Int. 2018;2018:e5201786. https://doi. org/10.1155/2018/5201786

16. Costa SC, Detoni $\mathrm{CB}$, Branco $\mathrm{CR}$, Botura MB, Branco A. In vitro photoprotective effects of Marcetia taxifolia ethanolic extract and its potential for sunscreen formulations. Rev Bras Farmacogn. 2015;25(4):413-8. https://doi.org/10.1016/j.bjp.2015.07.013

17. Lesser M, Turtle S, Farrell J, Walker C. Exposure to ultraviolet radiation (290-400 $\mathrm{nm}$ ) causes oxidative stress, DNA damage, and expression of p53/p73 in laboratory experiments on embryos of the spotted salamander, Ambystoma maculatum. Physiol Biochem Zool. 2001;74(5):733-41.

PMid:11517458

18. Zhang QW, Lin LG, Ye WC. Techniques for extraction and isolation of natural products: A comprehensive review. Chin Med. 2018;13:e20. https://doi.org/10.1186/s13020-018-0177-x PMid:29692864

19. Saewan N, Jimtaisong A. Photoprotection of natural flavonoids. J Appl Pharm Sci. 2013;3(9):129-41. https://doi.org/10.7324/ JAPS.2013.3923

20. He H, Li A, Li S, Tang J, Li L, Xiong L. Natural components in sunscreens: Topical formulations with sun protection factor (SPF). Biomed Pharmacother. 2020;134:e111161. https://doi. org/10.1016/j.biopha.2020.111161 PMid:33360043

21. Cozzi AC, Perugini P, Gourion-Arsiquaud S. Comparative behavior between sunscreens based on free or encapsulated UV filters in term of skin penetration, retention and photo-stability. Eur J Pharm Sci. 2018;121:309-18. https://doi.org/10.1016/j. ejps.2018.06.001

PMid:29874551

22. Rinayanti A, Pertiwi R. In vitro and in vivo sunscreen activity of active compounds isolated from fruits of Phaleria marcocarpha (Scheff.) Boerl. J Young Pharm. 2018;10(Suppl 2):s106-10. https://doi.org/10.5530/jyp.2018.2s.21

23. Lourith N, Kanlayavattanakul M, Chingunpitak J. Development of sunscreen products containing passion fruit seed extract. Braz J Pharm Sci. 2017;53:e16116. https://doi.org/10.1590/ s2175-97902017000116116

24. Osterwalder $U$, Herzog B. Sun protection factors: World wide confusion. Br J Dermatol. 2009;161(Suppl 3):13-24. https://doi. org/10.1111/j.1365-2133.2009.09506.x

25. Liang $\mathrm{CP}$, Chang $\mathrm{CH}$, Liang $\mathrm{CC}$, Hung $\mathrm{KY}$, Hsieh $\mathrm{CW}$. In vitro antioxidant activities, free radical scavenging capacity, and tyrosinase inhibitory of flavonoid compounds and ferulic acid from Spiranthes sinensis (Pers.) Ames. Molecules. 2014;19(4):468194. https://doi.org/10.3390/molecules 19044681 PMid:24739930

26. Nguyen HX, Nguyen NT, Nguyen MH, Le TH, Van Do TN, Hung TM, et al. Tyrosinase inhibitory activity of flavonoids from Artocarpus heterophyllous. Chem Cent J. 2016;10:e2. https:// 
doi.org/10.1186/s13065-016-0150-7

PMid:26834825

27. Zuo AR, Dong HH, Yu YY, Shu QL, Zheng LX, Yu XY, et al. The antityrosinase and antioxidant activities of flavonoids dominated by the number and location of phenolic hydroxy groups. Chin Med. 2018;13:e51. https://doi.org/10.1186/ s13020-018-0206-9

PMid:30364385

28. Chyau CC, Tsai SY, Ko PT, Mau JL. Antioxidant properties of solvent extracts from Terminalia catappa leaves. Food Chem. 2002;78(4):483-8.
S0308-8146(02)00162-0

29. Addor FA. Antioxidants in dermatology. An Bras Dermatol. 2017;92(3):356-62. https://doi.org/10.1590/ abd1806-4841.20175697

PMid:29186248

30. Rahimah SB, Djunaedi DD, Soeroto AY, Bisri T. The the phytochemical screening, total phenolic contents and antioxidant activities in vitro of white oyster mushroom (Pleurotus ostreatus) preparations. Open Access Maced J Med Sci. 2019;7(15):240412. https://doi.org/10.3889/oamjms.2019.741

PMid:31666837 